\title{
The Use of Personal Protective Equipment for Medical Recorders and Health Information During Covid-19 Pandemic in Indonesia
}

\author{
Kori Puspita Ningsih* \\ Program Studi RMIK (D-3) \\ Universitas Jenderal Achmad Yani \\ Yogyakarta, Indonesia \\ puspitakori@gmail.com
}

\author{
Kuswanto Hardjo \\ Program Studi RMIK (D-3) \\ Universitas Jenderal Achmad Yani \\ Yogyakarta, Indonesia \\ kuswanto_hardjo@yahoo.co.id
}

\author{
Endang Purwanti \\ Program Studi RMIK (D-3) \\ Universitas Jenderal Achmad Yani \\ Yogyakarta, Indonesia \\ c.endang.p@gmail.com
}

\begin{abstract}
The 2019 Coronavirus (Covid-19) outbreak's existence requires health service facilities in Indonesia to focus on the principles of patient safety and the principles of staff safety. The purpose of this study was to determine the use of personal protective equipment for medical recorders and health information in the Covid-19 pandemic in Indonesia. This type of research is descriptive quantitative research. The sample of this study was 65 health service facilities. Data collection techniques using questionnaires and interviews. Data analysis techniques using descriptive statistics. The analysis was carried out to determine the distribution of the use of types of personal protective equipment for medical recorders and health information in the Covid-19 pandemic. The results showed that the use of personal protective equipment for medical recorders and health information in the Covid-19 pandemic included the use of $100 \%$ masks, with 59 types of surgical masks $(\mathbf{9 0 . 8 \%})$ while cloth masks $(\mathbf{9 . 2 \%})$, gloves $(\mathbf{7 2 . 3})$ and before and after activities using a hand sanitizer $(\mathbf{1 0 0 \%})$. In comparison, soap with running water was only $(46.4 \%)$. Other personal protective equipment used by medical recorders and health information in Indonesia includes hazmat suits $(\mathbf{2 7 . 7 \%})$, face shields $(\mathbf{2 6 . 2 \%})$, eye protection (goggles) $(21.5 \%)$. It can be concluded that the application of personal protective equipment for medical recorders and health information in Indonesia is not entirely following the PORMIKI Circular Letter No.HM.01.01 / 002 / III / 2020 so it is necessary to educate and socialize the importance of personal protective equipment, especially in the use of gloves.
\end{abstract}

Keywords - personal protective equipment, medical recorders and health information, Covid-19

\section{INTRODUCTION}

The 2019 Coronavirus (Covid-19) disease outbreak, which originated in Wuhan, China, in December 2019, has been declared a public health emergency of international concern by the world health agency known as the World Health Organization [1]. As a countermeasure, most China regions have adopted responsive measures in the face of this fastspreading disease. However, some preventive measures that have been taken have no scientific basis and are ineffective [2].

The first countermeasure step that tends to be applied is air disinfection. Although Covid-19 is known to be spread through the air route, air disinfection in cities and communities are known to be ineffective for disease control and should be stopped. The use of alcohol and chlorine to all human body surfaces will harm clothing and mucous membranes such as eyes and mouth [1]. According to data from the National Health Commission of the People's Republic of China (2020), the use of personal protective equipment must take into account risk factors, types of illness, and savings on personal protective equipment due to the limited number. Furthermore, since the outbreak of COVID19 , the practice of blocking traffic and locking villages (lockdown) carried out by each town and community to close roads has been of no value. Such actions can even lead to civil unrest and reduce public compliance with infection prevention and control advice [2]

Health service facilities as the main actors and play an essential role in curative efforts in handling Covid-19 patients need more attention from the Government. There were 228 cases of health workers who died from the Covid-19 virus, including 127 doctors, 92 nurses, and 9 other health workers [3]. This requires health care facilities in Indonesia to focus not only on patient safety principles but also on staff safety principles.

The prevention and control of Covid-19 virus infection in health care facilities in Indonesia consists of 4 pillars, namely managerial, administrative management, environmental control, and control with personal protective equipment (PPE) [4]. Health workers need the right PPE for prevention, including the type of PPE, how to install, remove, and dispose of PPE [5]. PPE is just one effective measure in a package of administrative and environmental controls and techniques, as described in the prevention and control of acute respiratory infections that are prone to epidemics and pandemics in health [4]. Meanwhile, according to [6] PPE is an effective method of prevention of transmission as long as its rational use.

Medical recorders and health information are among health workers who are at risk of contracting the Covid-19 virus in health care facilities. This study aimed to determine the use of personal protective equipment (PPE) for medical recorders and health information on the Covid-19 pandemic in Indonesia.

\section{METHODS}

This type of research is descriptive qualitative research, meaning that the data analyzed is not to accept or reject the 
hypothesis (if any). Still, the results of the analysis are in the form of a description of the observed symptoms, which do not always have to be in the form of numbers or coefficients between variables. A quantitative approach is used in analyzing the characteristics of respondent health service facilities, the distribution of the use of personal protective equipment (PPE) and specify of medical recorders and health information in patient registration. This research was conducted in April-May 2020. The study population was all health service facilities in Indonesia. The sample of this study used purposive sampling, which represented as many as 65 health service facilities in Indonesia, consisting of 2 private clinics/doctors' practice (3.1\%), 17 health centers (26.2\%), 26 private hospitals $(40.0 \%), 17$ Regional General Hospitals (26.2\%) and 3 Central General Hospitals (4.6\%). Data collection techniques using questionnaires and interviews. Researchers send questionnaires to respondents via a google form. To ensure the validity of the questionnaire, the respondent must fill in his / her identity. This method used to collect characteristics of respondent health service facilities, the distribution of the use of personal protective equipment (PPE) and specificity of medical recorders and health information in patient registration. Interviews are used to obtain verbal data on research problems. Data analysis techniques using descriptive statistics. The analysis was carried out to determine the distribution of personal protective equipment for medical recorders and health information in the Covid-19 pandemic.

\section{RESULT AND DISCUSSIONS}

\section{A. Characteristics of Respondent Health Service Facilities}

The distribution of respondents based on demographics in this study includes Sumatra (3.1\%), DKI Jakarta and West Java and its surroundings (9.2\%), DIY (43.1\%), Central Java (23.1\%), East Java (6.2\%), Kalimantan, Riau Islands, Nusa Tenggara and papua (1.5\%) (Table 1$)$.

TABLE I. DEMOGRAPHIC DistRIBUTION

\begin{tabular}{|l|c|c|c|c|c|c|c|}
\hline Regional & $\begin{array}{c}\text { Clinic/Pri } \\
\text { vate } \\
\text { Clinic }\end{array}$ & $\begin{array}{c}\text { Public } \\
\text { Health } \\
\text { Service }\end{array}$ & $\begin{array}{c}\text { Private } \\
\text { Hospital }\end{array}$ & $\begin{array}{c}\text { Regional } \\
\text { Public } \\
\text { Hospital }\end{array}$ & $\begin{array}{c}\text { Central } \\
\text { Public } \\
\text { Hospital }\end{array}$ & Total (n) & $\begin{array}{c}\text { Percentage } \\
(\%)\end{array}$ \\
\hline Sumatera & & & & 1 & 1 & 2 & $3.1 \%$ \\
\hline DKI Jakarta & & & 4 & 2 & & 6 & $9.2 \%$ \\
\hline Jawa Barat \& the surondings & & 1 & 4 & 1 & & 6 & $9.2 \%$ \\
\hline DIY & 1 & 8 & 13 & 6 & & 28 & $43.1 \%$ \\
\hline Jawa Tengah & & 5 & 2 & 5 & 3 & 15 & $23.1 \%$ \\
\hline Jawa Timur & 1 & 1 & 1 & 1 & & 4 & $6.2 \%$ \\
\hline Kalimantan timur & & & 1 & & & 1 & $1.5 \%$ \\
\hline kepulauan riau & & & & 1 & & 1 & $1.5 \%$ \\
\hline Nusa tenggara & & 1 & & & & 1 & $1.5 \%$ \\
\hline Papua & 2 & 16 & 26 & 17 & 4 & 65 & $100.0 \%$ \\
\hline Total (n) & $3.1 \%$ & $24.6 \%$ & $40.0 \%$ & $26.2 \%$ & $6.2 \%$ & $100.0 \%$ & \\
\hline Percentage (\%) & & & & & & &
\end{tabular}

Types of medical records used in health care facilities in Indonesia include manual medical records (55.4\%), manual and electronic medical records (hybrid) (43.1\%), and electronic medical records (1.5\%) (Table 2). A medical record is a file containing notes and documents regarding the patient's identity, examination, treatment, actions, and other services to patients [7]. Medical records are needed by health care facilities to provide information obtained from recording and processing patient data so that management can use it to establish policies, make decisions, and evaluate matters relating to the services offered [8].

Based on table 2, it can be stated that $43.1 \%$ of health service facilities in Indonesia have started to switch from manual to electronic medical records. The use of electronic medical records has the potential to provide significant benefits for health services. One of the benefits felt after the use of electronic medical records is the increased availability of electronic patient records in hospitals [9]. It is also beneficial for patients as it increases efficiency in the health care process [10]. Research results by Robert et al. (2020) recommend that documenting using electronic medical records will protect staff, save PPE, and provide quick access to the care of Covid-19 patients [11].

TABLE II. TYPES OF MEDICAL RECORDS

\begin{tabular}{|l|c|c|c|c|c|c|}
\hline \multirow{2}{*}{ Type of medical Record } & \multicolumn{3}{|c|}{ Total (n) } & \multicolumn{3}{c|}{ Percentage (\%) } \\
\cline { 2 - 8 } & $\begin{array}{c}\text { Manual } \\
\text { medical } \\
\text { record }\end{array}$ & $\begin{array}{c}\text { Manual \& } \\
\text { electronic } \\
\text { medical } \\
\text { record } \\
\text { (hybrid) }\end{array}$ & $\begin{array}{c}\text { Electronic } \\
\text { medical } \\
\text { record }\end{array}$ & $\begin{array}{c}\text { Manual } \\
\text { medical } \\
\text { record }\end{array}$ & $\begin{array}{c}\text { Manual \& } \\
\text { electronic } \\
\text { medical } \\
\text { record } \\
\text { (hybrid) }\end{array}$ & $\begin{array}{c}\text { Electronic } \\
\text { medical } \\
\text { record }\end{array}$ \\
\hline Clinic/Private Clinic & 2 & & & $3.1 \%$ & $0.0 \%$ & $0.0 \%$ \\
\hline Public Health Service & 6 & 10 & 1 & $9.2 \%$ & $15.4 \%$ & $1.5 \%$ \\
\hline Private Hospital & 14 & 12 & & $21.5 \%$ & $18.5 \%$ & $0.0 \%$ \\
\hline Regional Public Hospital & 13 & 4 & & $20.0 \%$ & $6.2 \%$ & $0.0 \%$ \\
\hline Central Public Hospital & 1 & 2 & & $1.5 \%$ & $3.1 \%$ & $0.0 \%$ \\
\hline Grand Total & 36 & 28 & 1 & $55.4 \%$ & $43.1 \%$ & $1.5 \%$ \\
\hline
\end{tabular}

Furthermore, from the aspect of having internal regulations governing the mandatory use of PPE for medical recorders and health information in health care facilities at work, it was found that $78.5 \%$ of health care facilities had internal regulations (Table 3 ).

TABLE III. INTERNAL REGULATIONS

\begin{tabular}{|l|c|c|c|c}
\hline \multirow{2}{*}{ Internal Regulation } & \multicolumn{2}{|c|}{ Total (n) } & \multicolumn{2}{c}{ Percentage (\%) } \\
\cline { 2 - 5 } & Yes & No & Yes & No \\
\hline Clinic & 2 & & $3.1 \%$ & $0.0 \%$ \\
\hline $\begin{array}{l}\text { Public Health } \\
\text { Service }\end{array}$ & 12 & 5 & $18.5 \%$ & $7.7 \%$ \\
\hline Private Hospital & 24 & 2 & $36.9 \%$ & $3.1 \%$ \\
\hline $\begin{array}{l}\text { Regional Public } \\
\text { Hospital }\end{array}$ & 12 & 5 & $18.5 \%$ & $7.7 \%$ \\
\hline $\begin{array}{l}\text { Central Public } \\
\text { Hospital }\end{array}$ & 1 & 2 & $1.5 \%$ & $3.1 \%$ \\
\hline Grand Total & 51 & 14 & $78.5 \%$ & $21.5 \%$ \\
\hline
\end{tabular}

The Indonesian government has issued several regulations in order to accelerate the response to Covid-19 in the workplace through Presidential Decree No. 7 of 2020, dated March 13, 2020, concerning the Task Force for the Acceleration of Handling COVID-19 [12], Decree of the Minister of Health Number HK.01.07 / Menkes / 104/2020 concerning Determination of Novel Coronavirus Infection (2019-nCoV Infection) as a Disease that Can Cause Outbreaks and efforts to overcome it [13] and Circular of the SecretaryGeneral of the Ministry of Health of the Republic of Indonesia No. PK. 02.01 / B. VI / 839/2020 dated March 5, 2020, concerning Appeals for Efforts to Prevent the Transmission of COVID-19 in the Workplace [14]. With this regulation, it is hoped that it can prevent the transmission of the Covid-19 Virus in the workplace, and there is support from the workplace for the provision of PPE. 
The results of this study indicate that PPE for medical recorders and health information in the workplace is $98.5 \%$ always available (table 4).

TABLE IV. AVAILABILITY OF PPE

\begin{tabular}{|l|c|c|c|r|r|r|}
\hline \multirow{2}{*}{ Avaibility of PPE } & \multicolumn{3}{c|}{ Total $(\mathrm{n})$} & \multicolumn{3}{c}{ Percentage (\%) } \\
\cline { 2 - 7 } & No & Rarely & Yes, Always & No & Rarely & Yes, Always \\
\hline Clinic/Private Clinic & & & 2 & $0.0 \%$ & $0.0 \%$ & $3.1 \%$ \\
\hline Public Health Service & & 1 & 16 & $0.0 \%$ & $1.5 \%$ & $24.6 \%$ \\
\hline Private Hospital & & & 26 & $0.0 \%$ & $0.0 \%$ & $40.0 \%$ \\
\hline Regional Public Hospital & & & 17 & $0.0 \%$ & $0.0 \%$ & $26.2 \%$ \\
\hline Central Public Hospital & & & 3 & $0.0 \%$ & $0.0 \%$ & $4.6 \%$ \\
\hline Grand Total & 0 & 1 & 64 & $0.0 \%$ & $1.5 \%$ & $98.5 \%$ \\
\hline
\end{tabular}

\section{B. Personal Protective Equipment for Medical Recorders} and Health Information in the Medical Record Work

\section{Unit}

In general, the medical record work unit's activities are divided into two areas, namely (1) the administrative area for processing and storing medical records, and (2) the patient service area for patient registration activities, both outpatient, inpatient, and emergency. According to WHO (2020), administrative regions of health care facilities that are not in contact with Covid-19 patients do not require PPE However, according to the Professional Association of Medical Recorders and Health Information Indonesia (PORMIKI), to protect medical recorders and health information in a situation of the Covid-19 outbreak, personal protective equipment is needed while carrying out work, including masks (surgical masks are recommended), gloves (recommended gloves), Surgical hands, available hand sanitizer and always wash hands either using soap and running water or hand sanitizer, before and after doing activities [15].

This study showed that the PPE mask used by medical recorders and health information in the medical record work unit was $90.8 \%$ using surgical masks and $9.2 \%$ using cloth masks (reusable) (table 5).

TABLE V. MASKS

\begin{tabular}{|l|c|c|c|c|}
\hline \multirow{2}{*}{\multicolumn{1}{c}{ Mask }} & \multicolumn{2}{c|}{ Total (n) } & \multicolumn{2}{c|}{ Percentage (\%) } \\
\cline { 2 - 5 } & $\begin{array}{c}\text { Surgical } \\
\text { mask }\end{array}$ & $\begin{array}{c}\text { Cloth } \\
\text { mask } \\
\text { (reuse) }\end{array}$ & $\begin{array}{c}\text { Surgical } \\
\text { mask }\end{array}$ & $\begin{array}{c}\text { Cloth } \\
\text { mask } \\
\text { (reuse) }\end{array}$ \\
\hline Clinic/Private Clinic & 2 & & $3.1 \%$ & $0.0 \%$ \\
\hline Public Health Service & 17 & & $26.2 \%$ & $0.0 \%$ \\
\hline Private Hospital & 23 & 3 & $35.4 \%$ & $4.6 \%$ \\
\hline Regional Public Hospital & 14 & 3 & $21.5 \%$ & $4.6 \%$ \\
\hline Central Public Hospital & 3 & & $4.6 \%$ & $0.0 \%$ \\
\hline Grand Total & 59 & 6 & $90.8 \%$ & $9.2 \%$ \\
\hline
\end{tabular}

Masks are personal protective equipment, which can be the first barrier if there are droplets from both oneself and other people [16]. Masks recommended for medical recorders and health information during work are surgical masks [15]. Surgical masks are personal protective equipment that must be used for officers from the risk of being exposed to the transmission of the Covid-19 virus through droplets and contact with patients. Meanwhile, the cloth mask is used when you experience respiratory problems, and when you leave the house [13].

Furthermore, the use of surgical gloves (gloves) by medical recorders and health information in the medical record work unit was $72.3 \%$ (table 6 ). This shows that the use of surgical gloves by medical recorders and health information is not optimal in Indonesia, because gloves (surgical gloves are recommended) are one of the PPE recommended by PORMIKI to be used when medical recorders and health information perform their work [15]. Gloves are PPE that must be used for officers from the risk of being exposed to the transmission of the Covid-19 virus through airborne droplets and pads when in contact with patients and patient body fluids [13].

The culture of washing hands using clean hands before and after activities has been $100 \%$ carried out by medical recorders and health information during work (table 7). This is the following [15] that in the medical record work unit, it is recommended that hand sanitizers be available and always wash hands either using soap and running water or hand sanitizer before and after carrying out activities.

TABLE VI. SURGICAL GLOVES (GLOVES)

\begin{tabular}{|l|r|r|r|r|}
\hline \multirow{2}{*}{ Gloves } & \multicolumn{2}{c|}{ Total (n) } & \multicolumn{2}{c}{ Percentage (\%) } \\
\cline { 2 - 6 } & Yes & No & \multicolumn{1}{c}{ Yes } & No \\
\hline Clinic/Private Clinic & 2 & & $3.1 \%$ & $0.0 \%$ \\
\hline Public Health Service & 14 & 3 & $21.5 \%$ & $4.6 \%$ \\
\hline Private Hospital & 15 & 11 & $23.1 \%$ & $16.9 \%$ \\
\hline Regional Public Hospital & 14 & 3 & $21.5 \%$ & $4.6 \%$ \\
\hline Central Public Hospital & 2 & 1 & $3.1 \%$ & $1.5 \%$ \\
\hline Grand Total & 47 & 18 & $72.3 \%$ & $27.7 \%$ \\
\hline
\end{tabular}

TABLE VII. WASH HANDS USING A HAND SANITIZER

\begin{tabular}{|l|r|r|}
\hline Hand Sanitizer & Total (n) & Percentage (\% \\
\hline Clinic/Private Clinic & 2 & $3.1 \%$ \\
\hline Public Health Service & 17 & $26.2 \%$ \\
\hline Private Hospital & 26 & $40.0 \%$ \\
\hline Regional Public Hospital & 17 & $26.2 \%$ \\
\hline Central Public Hospital & 3 & $4.6 \%$ \\
\hline Grand Total & 65 & $100.0 \%$ \\
\hline
\end{tabular}

The culture of washing hands using running water is less attractive to medical recorders and health information because it only reaches $64.6 \%$ (table 8 ). Washing your hands using soap and running water takes 40-60 seconds [13].

TABLE VIII. WASH HANDS USING SOAP AND RUNNING WATER

\begin{tabular}{|l|c|c|c|c|}
\hline \multirow{2}{*}{\multicolumn{1}{c}{ Hand wash }} & \multicolumn{2}{|c}{ Total $(\mathrm{n})$} & \multicolumn{2}{c}{ Percentage (\%) } \\
\cline { 2 - 5 } & Yes & No & Yes & No \\
\hline Clinic/Private Clinic & 1 & 1 & $1.5 \%$ & $1.5 \%$ \\
\hline Public Health Service & 10 & 7 & $15.4 \%$ & $10.8 \%$ \\
\hline Private Hospital & 17 & 9 & $26.2 \%$ & $13.8 \%$ \\
\hline Regional Public Hospital & 12 & 5 & $18.5 \%$ & $7.7 \%$ \\
\hline Central Public Hospital & 2 & 1 & $3.1 \%$ & $1.5 \%$ \\
\hline Grand Total & 42 & 23 & $64.6 \%$ & $35.4 \%$ \\
\hline
\end{tabular}

\section{Specificity of Medical Recording Personal Protective Equipment and Health Information in Patient Registration}

This study also provides an overview of PPE's use in Indonesia, which is used by medical recorders and health information while on duty inpatient registration during the Covid-19 outbreak situation. According to WHO (2020), 
officers who carry out tasks in the patient screening area by conducting interviews require surgical masks and gloves [5].

The results showed $27.7 \%$ or as many as 18 health care facilities used hazmat as PPE used by medical recorders and health information while on duty inpatient registration (table 9).

The use of hazmat is a proactive effort to protect medical recorders and health information when in contact with patients while serving at patient registration. Surgical gown / reusable surgical gown (hazmat) is PPE that must be used for officers from the risk of being exposed to the transmission of the Covid-19 virus through airborne droplets and contact with patients and patient body fluids [13]

Furthermore, $26.2 \%$ or 17 health care facilities used face shields as PPE used by medical recorders and health information while on duty inpatient registration (table 10). The face shield is a PPE that must be used for officers from the risk of being exposed to the transmission of the Covid-19 virus through the airborne that triggers aerosols and during patient contact [13].

TABLE IX. HAZMAT

\begin{tabular}{|l|c|c|c|c}
\hline \multirow{2}{*}{\multicolumn{1}{c}{ Hazmat suit }} & \multicolumn{2}{c|}{ Total $(\mathrm{n})$} & \multicolumn{2}{c}{ Percentage (\%) } \\
\cline { 2 - 5 } & Yes & No & Yes & No \\
\hline Clinic/Private Clinic & & 2 & $0.0 \%$ & $3.1 \%$ \\
\hline Public Health Service & 7 & 10 & $10.8 \%$ & $15.4 \%$ \\
\hline Private Hospital & 6 & 20 & $9.2 \%$ & $30.8 \%$ \\
\hline Regional Public Hospital & 3 & 14 & $4.6 \%$ & $21.5 \%$ \\
\hline Central Public Hospital & 2 & 1 & $3.1 \%$ & $1.5 \%$ \\
\hline Grand Total & 18 & 47 & $27.7 \%$ & $72.3 \%$ \\
\hline
\end{tabular}

TABLE $X$. FACE SHIELD

\begin{tabular}{|l|c|c|c|c}
\hline \multirow{2}{*}{\multicolumn{1}{c|}{ Faceshield }} & \multicolumn{2}{c|}{ Total $(\mathrm{n})$} & \multicolumn{2}{c}{ Percentage (\%) } \\
\cline { 2 - 5 } & Yes & No & Yes & No \\
\hline Clinic/Private Clinic & & 2 & $0.0 \%$ & $3.1 \%$ \\
\hline Public Health Service & 7 & 10 & $10.8 \%$ & $15.4 \%$ \\
\hline Private Hospital & 5 & 21 & $7.7 \%$ & $32.3 \%$ \\
\hline Regional Public Hospital & 3 & 14 & $4.6 \%$ & $21.5 \%$ \\
\hline Central Public Hospital & 2 & 1 & $3.1 \%$ & $1.5 \%$ \\
\hline Grand Total & 17 & 48 & $26.2 \%$ & $73.8 \%$ \\
\hline
\end{tabular}

This study also shows that $21.5 \%$ of Indonesia's healthcare facilities use google glasses to protect medical recorders and health information while on duty inpatient registration during the Covid-19 outbreak situation (Table 11).

TABLE XI. GoOgLE GLASSES

\begin{tabular}{|l|c|c|c|c|}
\hline \multirow{2}{*}{\multicolumn{1}{c|}{ Google }} & \multicolumn{2}{c|}{ Total $(\mathrm{n})$} & \multicolumn{2}{c}{ Percentage (\%) } \\
\cline { 2 - 5 } & Yes & No & Yes & No \\
\hline Clinic/Private Clinic & & 2 & $0.0 \%$ & $3.1 \%$ \\
\hline Public Health Service & 4 & 13 & $6.2 \%$ & $20.0 \%$ \\
\hline Private Hospital & 5 & 21 & $7.7 \%$ & $32.3 \%$ \\
\hline Regional Public Hospital & 3 & 14 & $4.6 \%$ & $21.5 \%$ \\
\hline Central Public Hospital & 2 & 1 & $3.1 \%$ & $1.5 \%$ \\
\hline Grand Total & 14 & 51 & $21.5 \%$ & $78.5 \%$ \\
\hline
\end{tabular}

This study also describes the patient registration condition, which $100 \%$ has implemented a distance of 1 meter between the registration officer and the patient. The distance between the registration officer and the patient is at least 1 meter, and it will be better if the patient registration room is provided with a glass cover with a small hole as a face-to-face communication tool and a spot for submitting forms required at registration. Online patient registration or using a particular computer is also recommended [15].

\section{CONCLUSION}

Personal protective equipment for medical recorders and health information in Indonesia does not entirely follow PORMIKI Circular Letter No.HM.01.01 / 002 / III / 2020, so it is necessary to educate and socialize the importance of personal protective equipment, especially in surgical gloves (gloves) as a proactive effort to protect medical recorders and health information while performing work in situations of the Covid-19 outbreak.

\section{REFERENCES}

[1] WHO. Novel coronavirus (2019-nCoV) situation report 11. 2020; Available from: https://www.who.int/docs/defaultsource/coronaviruse/situation-reports/20200131-sitrep-11ncov.pdf?sfvrsn=de7c0f7_4

[2] Xiao, Y. \& Torok ME. Taking the right measures to control COVID19. The Lancet Infectious Diseases. 2020; Available from: https://www.thelancet.com/journals/laninf/article/PIIS14733099(20)30152-3/fulltext

[3] Rezkisari I. 228 Nakes Died Due to Covid-19. Republika.co.id [Internet]. 2020; Available from: https://republika.co.id/berita/qhevd5328/228-nakes-menangkatakibat-covid19

[4] WHO. Prevention and control of acute respiratory infections (ARI) that are likely to become epidemic and pandemic in health care facilities WHO Interim Guidelines June 2007 WHO / CDS / EPR / 2007.6. Appl Sci. 2018; 8 (11).

[5] WHO. Rational use of personal protective equipment for coronavirus disease 2019 (COVID-19) and considerations during severe shortages. Who [Internet]. 2020; (April): 1-28. Available from: https://apps.who.int/iris/handle/10665/331695

[6] Susilo A, Rumende CM, Pitoyo CW, Santoso WD, Yulianti M, Sinto R, Singh G, Nainggolan L, Nelwan EJ, Khie L, Widhani A, Wijaya E, Wicaksana B, Maksum M, Annisa F, Jasirwan OM , Yunihastuti E, Treatment of T, New I, Pinere RD, Cipto R. Coronavirus Disease 2019: A Review of Recent Literature. A disease in Indonesia. 2020; 7 (1): 45-67.

[7] Ministry of Health. Regulation of the Minister of Health of the Republic of Indonesia Number 269 / Menkes / Per / III / 2008 concerning Medical Records. 2008.

[8] Nissaa K, Lestar T, Mulyono S. Development of Color Coded Medical Records Map (Folder) Design at Pandan Arang Hospital, Boyolali. 2014; (2): 158.

[9] Feby Erawantini, Eko Nugroho, Guardian Yoki Sanjaya SH. Electronic Medical Records: A Benefit Review In The Context of Basic Health Services. Fiki. 2013; 1 (1): 1-10.

[10] Wilcox L. Using the Electronic Medical Record to Keep Hospital Patients Informed. [Internet]. Sciences-New York [Internet] .; 2010. 11-4 p. Available from: http://techhouse.brown.edu/ dmorris/publications/WishPatientDispl aysCHI 2010.pdf

[11] Turer RW, Jones I, Rosenbloom ST, Slovis C, Ward MJ. Electronic personal protective equipment: A strategy to protect emergency department providers in the age of COVID-19. J Am Med Informatics Assoc. 2020; 27 (6): 967-71.

[12] President of the Republic of Indonesia. Presidential Decree No. 7 of 2020, 13 March 2020 concerning the Task Force for the Acceleration of Handling COVID-19 2. 2020. 
[13] Ministry of Health. Decree of the Minister of Health Number HK.01.07 / Menkes / 104/2020 concerning Determination of Novel Coronavirus Infection (Infection 2019-nCoV) as a Disease that Can Cause Outbreak and efforts to overcome it. 2020 .

[14] Ministry of Health. Circular of the Secretary General of the Indonesian Ministry of Health No. PK. 02.01 / B. VI / 839/2020 dated March 5, 2020 concerning the Appeal for Efforts to Prevent the Transmission of COVID-19 in the Workplace SURAT. 2020.
[15] PORMIKI. Circular Letter No HM.01.01 / 002 / III / 2020 Concerning Medical Recording Work Procedures and Health Information in Covid-19 Outbreak situations. Jakarta; 2020.

[16] Pratiwi AD. Description of the Use of Masks during the Covid-19 Pandemic in Communities in Muna Regency. Lit Inst. 2020; 52-7. 